IZA DP No. 5940

Economic Conditions at the Time of Birth and Cognitive Abilities Late in Life: Evidence from Eleven European Countries

Gabriele Doblhammer

Gerard J. van den Berg

Thomas Fritze

August 2011 


\title{
Economic Conditions at the Time of Birth and Cognitive Abilities Late in Life: Evidence from Eleven European Countries
}

\author{
Gabriele Doblhammer \\ University of Rostock, DZNE, Max Planck Institute for Demographic Research \\ and Rostock Center for the Study of Demographic Change
}

Gerard J. van den Berg

University of Mannheim, IFAU Uppsala, VU University Amsterdam and IZA

Thomas Fritze

German Center for Neurodegenerative Diseases (DZNE) and Rostock Center for the Study of Demographic Change

\author{
Discussion Paper No. 5940 \\ August 2011
}

IZA

P.O. Box 7240

53072 Bonn

Germany

Phone: +49-228-3894-0

Fax: +49-228-3894-180

E-mail: iza@iza.org

\begin{abstract}
Any opinions expressed here are those of the author(s) and not those of IZA. Research published in this series may include views on policy, but the institute itself takes no institutional policy positions.

The Institute for the Study of Labor (IZA) in Bonn is a local and virtual international research center and a place of communication between science, politics and business. IZA is an independent nonprofit organization supported by Deutsche Post Foundation. The center is associated with the University of Bonn and offers a stimulating research environment through its international network, workshops and conferences, data service, project support, research visits and doctoral program. IZA engages in (i) original and internationally competitive research in all fields of labor economics, (ii) development of policy concepts, and (iii) dissemination of research results and concepts to the interested public.
\end{abstract}

IZA Discussion Papers often represent preliminary work and are circulated to encourage discussion. Citation of such a paper should account for its provisional character. A revised version may be available directly from the author. 


\title{
ABSTRACT
}

\section{Economic Conditions at the Time of Birth and Cognitive Abilities Late in Life: Evidence from Eleven European Countries}

\begin{abstract}
With ageing populations and a stronger reliance on individual financial decision-making concerning asset portfolios, retirement schemes, pensions and insurances, it becomes increasingly important to understand the determinants of cognitive ability among the elderly. Macro-economic recession and boom periods provide a unique opportunity to study the effect of changes in the early life economic environment on late life cognition. In European countries, about three to four economic recession and boom periods can be identified between 1900 and 1945. The timing of these periods differs between the countries, which makes a cross-country study design particularly powerful, as it is insensitive to countryspecific confounding factors. We use data from the Survey of Health, Aging and Retirement in Europe (SHARE) among elderly individuals. This survey is homogeneous across countries. We use almost 20,000 respondents from 11 countries. We examine several domains of cognitive functioning at ages 60+ and link them to the macro-economic deviations in the year of birth, controlling for current demographic, socioeconomic and health status. We find that being born during a recession or boom period significantly influences cognitive functioning late in life in various domains. The effects are particularly pronounced among the less educated. Boom periods positively influence numeracy and verbal fluency as well as the score on the omnibus cognitive indicator. The results are robust; controlling for current characteristics does not change effect sizes and significance. We conclude that cognitive functioning late in life is influenced by economic conditions in the year of birth, and we discuss possible causal pathways.
\end{abstract}

JEL Classification: I12, I18, J14, N14, N34, J26

Keywords: cognition, economic business cycle, developmental origins, health, long-run effects, dementia, numeracy, memory, decision-making

Corresponding author:

Gerard J. van den Berg

University of Mannheim

Department of Economics

L7, 3-5

68131 Mannheim

Germany

E-mail: gerard@uni-mannheim.de

\footnotetext{
* Thanks to Björn Öckert, Lena Janys and Uta Ziegler for useful comments and discussions and to Daniel Kreft for help with the data.Van den Berg is Alexander von Humboldt Professor of Econometrics and Empirical Economics.
} 


\section{Introduction}

Many countries face a shift in the age composition of the population towards higher ages. Individuals aged above 60 face historically low mortality rates. At the same time, elderly individuals are more and more often expected to make their own decisions regarding retirement plans, health care and health insurance, and the portfolio allocation of their assets. If an individual's cognitive abilities are impaired, then it is more likely that such decisions are sub-optimal. A number of recent studies show that cognitive impairment adversely affects investment behaviour among elderly individuals. Low cognitive ability, as captured by indicators of mathematical, verbal, and recall skills, leads to a lower propensity among elderly individuals to invest in stocks and similar assets (1). A low numerical ability leads to low levels of retirement saving and investment portfolios (2). Total household wealth and financial wealth decreases when families choose the less numerate spouse as the financial decision maker in the family (3). With elderly individuals facing increasingly complex and frequent financial decision problems, cognitive impairment may therefore lead to a substantial welfare loss for their household.

Knowledge about the determinants of cognitive status among the elderly facilitates the identification of groups of elderly who are particularly at risk. This is also relevant from a health care policy point of view. After all, the costs of care for cognitively impaired individuals are high and are expected to increase in the upcoming decades.

In the present paper we examine the role of economic conditions early in life on cognitive functioning at old ages. The literature on the developmental origins of diseases provides evidence that exposure to adverse stimuli during the first stages of life may hinder the 
development of vital organs and the immune system, with irreversible negative effects on health at high ages (see the literature overview in the next section).

Economic conditions in the parents' household at birth and outcomes later in life are jointly dependent on unobserved confounders. We deal with this by using the state of the business cycle early in life as an indicator of economic conditions early in life. This follows (4-6), who focus on the effects of conditions at birth on mortality rates later in life. The underlying idea is that birth in a recession causes adverse economic conditions in many households. This may in turn lead to a low quality and/or quantity of nutrition, to adverse housing conditions, and to an enhanced stress level in the household. Birth in a boom year is expected to have the opposite effects. The business cycle is plausibly not affecting late-life health outcomes in other ways than through its effect on health and abilities around birth. An effect of the business cycle on late-life health outcomes is then evidence of a causal effect of early-life conditions on late-life health. ${ }^{1}$

The current elderly were born in times where exposure to a recession was a more intrusive event than nowadays. Generous social safety nets were largely absent. Macroeconomic recession and boom periods thus provide a unique opportunity to study the effect of changes in the early life economic environment on late life cognition. In European countries, about three to four economic recession and boom periods can be

1 (4) and (6) find significant causal effects on mortality and on cardiovascular mortality, respectively. Similar methodological approaches are used by (7), who demonstrates that survival at ages older than 50 is significantly affected by the season of birth, and by ( 8 , 9 ), who use variation in food prices early in life. These studies have in common that they exploit modest fluctuations in early-life conditions, and therefore the results are not driven by extreme events like severe famines or epidemics. 
identified between 1900 and 1945. These include recessions during World War I and the Great Depression in the early 1930s. However, the timing of boom and recession periods and the general economic development differ between countries, which makes a crosscountry study design particularly powerful.

We use data from the Survey of Health, Aging and Retirement in Europe (SHARE) among elderly individuals. This survey is designed to be homogeneous across countries. We use almost 20,000 respondents from 11 countries. We examine several domains of cognitive functioning at ages $60+$ and link them to the macro-economic deviations in the year of birth, controlling for current demographic, socioeconomic and health status.

We distinguish between different levels of education. On the one hand, the less educated may have had fewer resources to buffer against adverse economic conditions early in life, while they may benefit more from favorable conditions. This would make them more sensitive to the business cycle at birth. On the other hand, individuals born in poor families may be less likely to go to secondary school and learn how to keep their cognitive ability in shape, regardless of the business cycle at birth.

\section{Background}

Since the seminal studies of (10) and (11) about long-term effects of nutrition and infectious disease early in life on late life health and morbidity, an extensive literature has been documenting how the environment early in life influences adult health and socioeconomic outcomes. 
Effects of fetal undernutrition (10) on metabolic adaptation in utero may affect the phenotype such that the risk of cardiovascular disease later in life is increased (12-14). Underlying this model is the idea that several critical periods early in life influence the development of humans. During these periods, developing systems permanently modify their settings in response to social and biological cues (15). This includes durable epigenetic changes that modify gene expressions. Along this way, adverse socioeconomic conditions (16) and a harsh family climate in childhood (17) are known to influence inflammation, measured in terms of interleukin-6 production, in adolescence and adulthood, plausibly through changes in gene expressions. Stress induced early in life may thus engender a proinflammatory phenotype. Over time, this takes an allostatic toll on the body, resulting in a higher risk of chronic diseases later in life (16-21).

Rather than debilitation, such mechanisms may be seen as a predictive adaptive response to the future environment $(14,21)$. Humans, which constitute a long-lived species, should be protected against rapid developmental adaptation of metabolic traits to short-term changes in the environment. Changes may not be persistent over the whole life-course, so a complete adaptation could easily lead to a mismatch between the future environment and the developed metabolism $(14,22)$. Still, incomplete buffering may permanently modify the biology of the offspring (15). On the plus side, supportive family environments have been shown to be able to buffer the negative effects of low socioeconomic status on the development of a proinflammatory phenotype (23).

Childhood exposure to disease may trigger another pathway. Early infectious exposure can lead to a chronic activation of inflammatory pathways which influence morbidity and 
mortality in adulthood $(24,25)$ by increasing the risk for cardiovascular disease, type 2 diabetes, the metabolic syndrome, late-life disability and mortality (26). Childhood exposure to measles and typhoid affect cardiac and respiratory functioning later in life (27), while the exposure to small pox epidemics in the first year of life increases mortality from respiratory diseases at old age (9).

The human fetal brain is comparatively large and strongly glucose dependent. It is heavily protected during periods of shortage (12). During infancy and childhood the brain requires a large flow of energy of about half of resting metabolism (28), which may be compromised by nutritional and infectious disease stress (29). Early childhood may represent a particularly vulnerable time period, as the brain is undergoing rapid neurodevelopmental changes (30): adverse conditions during the brain development early in life may affect cognitive development and cognitive functioning later in life. Early life infections can compromise brain development among children, with some infections resulting in permanent impairment (e.g. the effect of malaria on the developing brain (31)). They can also influence cognitive decline through later life cardiovascular disease (32), or through the effects of inflammation on neurodegenerative disease such as dementia, Alzheimer's disease or Parkinson (see $(33,34)$ and references therein).

Accelerated telomere length shortening has been associated with ageing in general and cognitive decline in particular (35). Early-childhood adversity and distress may affect late-life cognitive decline through telomere length shortening (35). Two recent studies demonstrate an association between retrospectively reported childhood adversity and adult telomere length $(36,37)$. Childhood trauma is a significant risk factor for shorter 
leukocyte telomere length in adulthood (38). Children in institutional care as compared to those put in foster care have shorter telomere length already during childhood (30). Early childhood is both a period of rapid telomere attrition as well as a crucial time point for the epigenetically established individual rate of telomere length attrition $(39,40)$.

We now zoom into a few studies that explicitly relate cognitive functioning later in life with exogenous changes in nutrition and the environment in utero or in the first years of life. In fact, most of the outcomes in these studies are measured for prime-aged adults aged up to 60, which is not the sub-population of primary interest if one aims to study (as we do) mild cognitive impairments among individuals aged 60+. (41) finds no effects of exposure to the Dutch Hunger Winter famine during pregnancy on cognitive abilities at ages just below 60. (42) find an effect on a selective attention task but not on any other measure. $^{2}$ Prenatal exposure to the 1918 influenza pandemic reduces educational attainment in the US population (48). The infant mortality rate and the death rates from typhoid, malaria, measles, influenza, and diarrhea are negatively correlated with cognitive functioning measured as delayed word recall in the HRS (49).

Notice that famines and epidemics constitute severe shocks and hence may give rise to disproportionally large effects and/or to effect attenuation due to selective births. (50) finds that among individuals born in the Netherlands under adverse economic conditions

2 Related to this are studies on effects of in-utero famine on severe mental disorders and disabilities at prime ages. An elevated risk of schizophrenia at adult ages has been found for both genders (e.g. (43-45) and the survey in (46)). The occurrence of Ramadan during the first month of pregnancy increases the risk of disability, in particular related to mental/learning disabilities, in the Muslim populations in Uganda and Iraq (47). 
as captured by mild exogenous shocks, the decline in mental fitness after experiencing a negative life event at high ages, such as stroke, surgery, illness or death of a family member, is worse. That study focuses on cognitive decline rather than the level, and it uses the MMSE score as main outcome variable, which is more indicative of rather severe mental limitations than of common cognitive impairments. (51) experimentally study effects of mild psychological stress shortly after birth on cognitive outcomes at high ages among rats. They find that mild stress causes declines in memory functioning at high ages and they detect accompanying neurological changes. A recent study with human beings found that low socioeconomic status and poverty are associated with an increased allostatic load during childhood and to lower scores in young adults' subsequent working memory (52). The relationship between early life abilities and cognitive functioning as well as Alzheimer pathology late in life has been demonstrated in the so-called "nun studies" $(53,54)$ using idea density, a measure of linguistic ability in early life. About 60 years later, low idea density at age 22 was significantly related with poor cognitive functioning as assessed by neuropsychological tests (53) and the severity of Alzheimer's disease pathology in the neocortex (54). ${ }^{3}$ Clearly, our paper makes a significant contribution to the literature, in that we focus on individuals aged $60+$ while at the same time allowing for a wide geographical and temporal range of idiosyncratic shocks in early-life conditions. Moreover, we include mild cognitive

3 The mechanism behind this relationship is unknown (54). The hypothesis that a reduced neurocognitive reserve capacity has made those with low idea density early in life more vulnerable to the pathologies of Alzheimer disease later in life has not been verified. On the contrary, it seems that low linguistic ability early in life is an early expression of Alzheimers disease later in life (53). 
impairment outcomes, which are of particular societal relevance because of the fraction of individuals affected.

So far, we have mostly focused on biological causal effects of early-life conditions. A substantial literature provides evidence for the presence of short-run effects of economic conditions on the development of children's cognitive skills (see (55) and the overview in (56)). Such a short-run effect may be magnified by its influence on the realized individual level of education, making the effect persistent over time (57). This would constitute an indirect pathway in which educational achievement plays a crucial role.

\section{Materials and Methods}

\subsection{Data}

To measure cognitive functioning at age $60+$ we use data from the Survey of Health, Ageing and Retirement in Europe (SHARE), which has become a widely used data source for the analysis of the living conditions of the elderly. The first wave of SHARE was conducted in 2004 and 2005 in eleven countries representing the main regions in Europe covering Northern Europe (Sweden, Denmark), Central Europe (Austria, Germany, the Netherlands, France, Switzerland, Belgium) and Southern Europe (Spain, Italy, Greece). Additionally, Israel participated in SHARE's first wave in 2005 and 2006. In total, 31,115 persons were interviewed. The second wave, with 33,281 interviews, was conducted in most countries in 2006 and 2007. All countries of the first wave, with the exception of Israel, participated in the second wave. The Czech Republic, Poland and Ireland were added to the SHARE program in the second wave. 
The following analysis relies on the first two waves of SHARE (Releases 2.4.0) and includes all countries that participated in both waves (i.e. Sweden, Denmark, Austria, Germany, the Netherlands, France, Switzerland, Belgium, Spain, Italy, Greece). This enables us to differentiate between age and cohort effects. We only use respondents who participated in the first wave of SHARE, or responded for the first time to the second wave, or were part of the refreshment sample of the second wave. This design prevents effects of repeated interviewing with respondents knowing the questions and their answers beforehand. (58) show that the average score of cognitive functioning improves between the first and the second wave which may be the result of panel attrition as well as of repeated interviewing. Since Austria does not have a refreshment sample, the respondents from the second wave who are included in this study are individuals who did not answer the questionnaire in the first wave. Altogether, this study comprises 18,262 respondents aged 60+ born in the years 1900-1945 with known information about their cognitive status and born in one of the eleven countries. For Austria and Germany we restricted birth cohorts to the period 1900-1938 in order to omit a possible bias due to World War II. For Greece only the birth cohorts 1921-1945 are part of this study due to the lack of economic information before that period. Table 1 gives an overview of the study population by country and wave. About $47 \%$ of our sample is aged between 60 and 69 years, whereas $15 \%$ are 80 years and older.

Table 1 here 


\subsection{Measures of Cognitive Functioning in SHARE}

SHARE provides information on main domains of cognitive functioning identified in the cognitive psychology literature, namely orientation, memory, executive function and language. We examine five indicators of cognitive functioning in SHARE related to these domains and in addition construct a summary score.

First, orientation in time is measured by four questions about current day of the month, month, year, and day of the week. Every correct answer leads to one point, with a maximum of four points. We dichotomize the indicator distinguishing those with three or less correct answers from those who did not give any incorrect answer.

Second, recall ability is measured by a list of ten items where the respondent is asked which one he or she remembers within one minute. The items are: butter, arm, letter, queen, ticket, grass, corner, stone, book, and stick. Using recall ability as the dependent variable the number of correct recalls is counted. We use quintiles when combining the variable into the summary score: a maximum of four points are given when at least five items are recalled, followed by three points for four items, two points for three items, one point for two items, and zero points otherwise.

Third, delayed recall ability is measured after the numeracy and verbal fluency tests, where respondents have to repeat the recall. In terms of the summary score the rating is less strict, and four points are given for at least four recalled items, three points for three items, and so on. 
Fourth, numeracy ability is based on four questions. The construction of the numeracy score is based on (1). With the first question the respondent has to calculate $10 \%$ of 1,000 . If this question is answered incorrectly the respondent is asked the second question of how much half the price of a sofa that costs 300 Euros would be. If both questions are answered incorrectly zero points are assigned. One point is assigned if the first question is answered incorrectly, the second correctly. If the first question is answered correctly, the third question is asked which requires the calculation of the original price of a new car. The current price is 6,000 euro, and this is two-thirds of what it cost new. If this is answered correctly, too, a fourth question is asked about interest rates. In case the fourth question is answered correctly a maximum of four points is given, otherwise three points are assigned. We dichotomize the indicator distinguishing those with a maximum of one point from the rest.

Fifth, verbal fluency is measured by the respondent naming as many different animals as he/she can think of within one minute. Values are assigned according to quintiles: zero points are assigned if less than 12 animals are named, one point for 12 to 15 , two points for 16 to 18 , three points for 19-23, and four points for 24 and more animals.

Finally, we construct a summary score of cognitive functioning that ranges between 0 and 20 and consists of the sum of the points assigned in the individual indicators. The summary score is divided into the two categories: above and below the median: 9,789 individuals with scores between 0 and 14 are combined into the group "poor cognitive functioning", and 8,473 individuals with scores between 15 and 20 comprise the group "good cognitive functioning". We perform sensitivity analyses using different cut-points 
for the individual indicators as well as for the summary score, but the results turn out to be insensitive.

Figure 1 here

Figure 1 shows the frequency distributions of the single items orientation in time (A), first recall (B), verbal fluency (C), numeracy (D), delayed recall (E), summary score (F). The single items are all significantly correlated (SC-Spearman correlation, $\mathrm{p}=0.00$ ), the correlation is highest between immediate and delayed recall $(\mathrm{SC}=0.71)$, followed by verbal fluency and the recall items ( $\mathrm{SC}$ first recall $=0.51$; $\mathrm{SC}$ delayed recall $=0.47$ ). Numeracy is closely related to verbal fluency and the recall items (ranging between 0.40 and 0.47 ), while orientation in time is the least correlated with the other items.

\subsection{Economic Conditions at the Time of Birth}

Real GDP per capita is a widely used measure of aggregate economic conditions (4-6). To capture idiosyncratic shocks in economic conditions we use the cyclical component of the natural logarithm of real GDP per capita at the country-level, applying the HodrickPrescott Filter (59) with a smoothing value of 500. The GDP data are based on (60). The cyclical component of the business cycle is transformed into one indicator with three categories. The category "recession" applies to those years that belong to the lowest quartile $\left(=1^{\text {st }}\right)$ of the country-specific cycle. The category "average" applies to the second and third quartile. The third category, "boom", indicates years in the highest quartile 
$\left(=4^{\text {th }}\right)$. We link the year of birth with the cyclical component of the same year $(t)$. The year $t$ covers most or all of the first year of life for those born at the beginning of the year, and the period in-utero including up to three months before conception for those born at the end of the year. We also run models were we include year $\mathrm{t}-1$ and year $\mathrm{t}+1$. Depending on the exact month of birth in year $t$, year $t-1$ covers fetal development inutero and the time before conception: for those born at the beginning of year $t$, it includes the time in-utero plus a maximum of 3 months before conception; for those born at the end of year $\mathrm{t}$, it covers between 12 and 15 months prior to conception. Year $\mathrm{t}+1$ covers most of the first year of life born at the end of year $t$, and the second year of life for those born at the beginning of year t. Notice also that any recession in the earliest years is sooner or later followed by a boom, and vice versa.

Figures 2a-d show the cyclical component of GDP per capita for the eleven countries, while table 2 gives the exact boom and recession periods for each country. The average age of the respondents born during recession periods is 68.71 years, of those born during boom periods 71.09 years. This means that the results can not be driven by individuals born in booms having benefited more from secular improvements in society than individuals born in recessions.

It is conceivable that less-frail individuals are over-represented in birth cohorts born under adverse conditions. Such selectivity would bias our results towards zero (i.e., we would under-estimate a positive effect of favorable conditions at birth on cognitive ability later in life). However, previous studies have found no systematic dependence of the size 
and social-class composition of birth cohorts on the business cycle, in European countries in the pre-1945 years (see (6) for an overview and for additional references).

Figures $2 \mathrm{a}$ to $\mathrm{d}$ here

Table 2 here

\subsection{Empirical Strategy}

We use multilevel regression models with 2 levels (individual and country) and varyingintercepts, to explore the effect of the business cycle on cognitive functioning for all countries combined. Individual characteristics as well as the indicator distinguishing the boom, average and the recession periods are fixed effects whereas the country-specific indicators are included as random effects. Depending on the indicator of cognitive functioning we use a logit (summary score, orientation in time, numeracy) or a linear link function (verbal fluency, first recall, delayed recall). The linear link function transforms the dependent variables by adding the number one to the score and taking the natural logarithm.

We estimate equations of the form

$$
y_{i c t}=\beta_{0}+\sum_{j=t-1}^{t+1}\left(\beta_{j} * i n d_{c j}\right)+\gamma X+\delta Z+\varepsilon_{i c t}
$$


where $y_{i c t}$ is a measure of cognitive functioning at age $60+$ for individual $i$ in country $c$ born in year $t, i n d_{c j}$ is a fixed effects indicator for a recession, average or boom period in the country $c$ and the years $j=t, t-1, t+1 . \mathbf{X}$ is a matrix of fixed-effects individual level characteristics, $\mathbf{Z}$ a matrix of the random effects country-level dummies, $\beta_{0}, \beta_{j}, \gamma$, and $\delta$ are the respective parameters and $\varepsilon_{i c t}$ is the error term. ${ }^{4}$

We apply a nested modeling strategy. A set of first models includes as explanatory variables the indicator for the recession, average and boom periods in year $t$, age of the individual in five year age groups up to age 90+, sex and education, a dummy variable for birth in the years of World War I (WWI; note that this strongly overlaps with the 85-89 age interval), as well as the country-specific dummy variables. Education is based on the International Standard Classification of Education (ISCED). Respondents with at least post-secondary education are assigned to the category high education whereas those with secondary education or less are assigned to low education. A third category comprises "refusal", "don't know", "still in school", and "other". We then perform separate estimations by education.

Having first-time respondents from the first as well as the second wave of SHARE means that we observe individuals from the same country with the same age who were in different stages of the business cycle at birth. This contrasts to a simple cross-sectional

\footnotetext{
4 We also estimate level-1 regression-type models where country dummies are included as additional individual explanatory variables instead of as random effects. However, the results (not shown) are essentially the same as those reported here. The advantage of that approach is that the country effect does not have to be independent from the other covariates.
} 
sample of individuals from a given country. With the latter type of sample, age effects are not identified from calendar time trends due to secular improvements in society, and a comparison between births from favourable and adverse years may be determined by age differences.

A second set of models includes the business cycle indicator for the year before and after the birth year. Finally, in a third step a rich set of covariates covering current demographic and health aspects of the individuals is included. The family status gives information about whether respondents are living together with a partner or not, the number of children is grouped into five categories ranging from childless to four children and more. We use body mass index (BMI) and smoking behaviour to control for risk factors of cognitive functioning. Body-mass index differentiates between respondents with underweight (BMI below 18.5), normal weight (18.5-24.9), overweight (25.0-29.9), and obesity (30.0 and above), besides a category for refusals, don't know, and missing answers. Smoking behaviour distinguishes between current smokers, previous smokers and never smokers, and a residual category of missing answers.

Disability is measured in terms of limitations in the activities of daily living (ADL) differentiating between respondents with at least one limitation and those with none. We use the EURO-D scale to measure depression which ranges between from 0 (not depressed) to 12 (very depressed). We attribute depression symptoms to respondents with values five and above. We control for whether the items, other than the cognitive functioning variables, were answered by a proxy or by the respondent. 
The morbidity part includes 14 dummy variables for chronic diseases. Respondents were asked whether a doctor ever told them that they have a certain disease or not. These diseases are heart attack, hypertension, high blood cholesterol, stroke, diabetes, chronic lung disease, asthma, arthritis, osteoporosis, cancer, stomach/duodenal/peptic ulcer, Parkinson disease, cataracts, and hip/femoral fracture. Table 3 gives an overview of the distribution of the covariates.

Table 3 here

The analyses require individuals to be alive at the time of their interview. Although the birth years are on average more recent than those used in typical long-run studies of early-life conditions (the vast majority of respondents being below age 75 at the time of the interview), it is of course a fact that a certain fraction of any birth cohort has died before the interview. This attrition plausibly leads to an overrepresentation of less frail (and more able) individuals within cohorts born under adverse conditions, which may bias our results towards zero (6).

\section{Results}

Table 4 presents our main results in the form of marginal probabilities. Rows correspond to the separate analyses of the six dependent variables, and the two columns depict the effects of an average and boom period relative to a recession period in the year of birth (t). For the two indicators of orientation in time and numeracy, and for the summary 
score, negative signs of the marginal probabilities indicate lower odds of poor cognitive functioning. For the single indicators verbal fluency, $1^{\text {st }}$ and delayed recall positive signs indicate better performance in cognitive functioning. The models control for the confounding effects of age, sex, education, WWI, and country. Below, when we refer to "boom periods" and "recession periods", we tacitly omit the qualification that these are periods early in life rather than periods later in life. Clearly, we expect differences between those born in boom and recession years to be more pronounced than differences between either of these two groups on the one hand and those born in average years on the other. However, the latter group is larger in number, and in some cases, when the contrast boom vs. recession does not give rise to a significant effect, the contrast boom vs. (recession+average), and/or the contrast (boom+average) vs. recession, gives rise to effects that are significantly different from zero.

Table 4 here

In general, the effects of boom, average and recession periods in the year of birth ( $t$ ) follow our expectations insofar that the former implicate lower risks of poor cognitive functioning late in life than the latter. Boom periods decrease the risk of poor cognitive functioning in terms of numeracy. The effect is particularly strong among the less educated $(-0.116, \mathrm{p}=0.038)$ but non-existent among the more educated. 
Results are similar for the indicators of verbal fluency and first recall. Birth in a boom year increases late-life ability scores: in terms of verbal fluency by $2.4 \%(p=0.05)$ and of first recall by nearly $5 \%(\mathrm{p}=0.183)$. Results in terms of second recall are inconsistent since they suggest a better performance for those being born in a recession period. However, the difference is not significant.

Combining all indicators into the over-all summary or omnibus score reveals that being born during a boom period reduces the risk of poor cognitive functioning. The effect size is $-0.123(\mathrm{p}=0.019)$ and stems from the less educated $(-0.163, \mathrm{p}=0.004)$. No effect exists among the more educated.

The second set of models includes cyclical indicators for the year prior to birth (t-1) and the year after birth $(\mathrm{t}+1)$ in addition to the year of birth ( $\mathrm{t})$. In general, results for the year of birth (t) remain stable, though some comparisons between boom and recession birth years lose statistical significance. Turning to the year prior to birth, booms show no significant effects. Turning to the year $\mathrm{t}+1$, orientation in time is positively influenced by boom periods $(-0.134, \mathrm{p}=0.064)$, while effects for the first and second recall are significant but contrary to our expectations.

Table 5 here

Effect sizes and significance of the business cycle indicator remain stable when current familial, social and health characteristics of the respondents are introduced into the 
models. Table 6 demonstrates this for the summary score. Results are similar for the individual items (not shown). Directions and significance levels of the effects of the control variables follow our expectations, supporting the validity of our summary score of cognitive functioning. Living without a partner significantly increases the odds of poor cognitive functioning, which is also true for respondents with four and more children as compared to the childless. This result confirms the findings of early studies on the importance of social contacts for good mental health (61-63) as well as of the increasing risk of depression with an increasing number of children (63). BMI is negatively related to poor cognitive functioning, reflecting the loss of body weight with morbidity in general and poor mental health in particular $(64,65)$. The effect for smoking is nonmonotone, with previous smokers having the lowest risk, a result also reported in other studies (66). The presence of ADL limitations as well as of depressive symptoms increases the risk. A series of studies report positive correlations with severe dementia (67-70). Morbidity patterns show that heart attack, stroke, diabetes and chronic lung disease, as well as Parkinson disease and cataracts are associated with a significant increase in poor cognitive functioning, whereas cancer patients have a significant lower risk.

Table 6 here 
We also estimate the basic logit model for the over-all summary score for each country separately. In the light of the small sample size per country (Table 1), it is not surprising that most estimates of interest are insignificantly different from zero (not shown). For 7 out of the 11 countries, the estimated effect of birth in a boom year (as compared to birth in a recession year) has the expected negative sign. In terms of coefficients size, the strongest effects are for Belgium, Germany and Sweden (all below -0.3).

As noted in the Background section, education may act as an intermediary between earlylife conditions and late-life cognitive ability. The over-all effect of conditions at birth may then be under-estimated when conditioning on the level of education in the models, as we have done so far. We therefore also estimate models where education is omitted as an explanatory variable. The results (not shown) are essentially the same as those reported in the paper. This suggests that an indirect causal pathway through education is quantitatively unimportant in the cohorts we consider. It should be noted, however, that, in the birth interval we consider, the variation in education is not large. Moreover, in a formal analysis one would prefer to have an instrumental variable for education in order to deal with its possible endogeneity.

\section{Discussion}

The existence of an economic boom during the year of birth reduces the risk of poor cognitive functioning at age 60 and above. Recessions tend to impair late life cognitive functioning. In our study all four domains of cognitive functioning, represented by six indicators, follow this pattern. The low educated benefit particularly from favorable 
periods early in life. Adding economic information for the year prior to birth and the year after birth to the model changes the results only marginally.

While the mechanisms underlying the effect of boom and recession periods on late life cognition cannot be easily determined, a series of possible links exist that are closely related to the present knowledge about causal pathways from early-life conditions to latelife health outcomes. Boom and recession periods plausibly differ in terms of the quality and quantity of nutrition as well as the psychological stress level in the household. In addition, differences in the extent of crowded housing and access to health care might create differences in disease exposure. Nutrition, disease exposure and stress early in life have all been connected to health outcomes late in life, including mental outcomes (recall the background literature discussion earlier in the paper).

The economic effect on pre-natal and early natal nutrition is likely to be of major importance. Recessions before 1945 involved income loss for many households. As discussed earlier, biological cues transmitted early in life may permanently modify the metabolic development, affecting cognitive abilities later in life. The cardiovascular and obesity effects of reduced nutrition in utero have been shown to be stronger if the affected individuals are exposed to a more favorable environment later in childhood (71). The latter by construction applies to the business cycle, since any recession is sooner or later followed by a boom.

In addition to direct nutritional effects, it is likely that economic hardships and the fear of hardships and the loss of employment and income in the near future increase the level of psychological stress in the household. Exposure to this in utero or shortly after birth may 
be neurodegenerative in such a way that cognitive abilities decline at high ages (51). Alternatively, more adverse socioeconomic conditions (16) and a harsher family climate in childhood (17) may lead to a proinflammatory phenotype and an accelerated telomere shortening (35), resulting in a heightened risk of chronic (cardiovascular) health problems and cognitive limitations later in life (17-20).

One major limitation of this study is that we cannot define the exact period of fetal or childhood development in relation to the GDP cycle. Information about GDP is given on an annual basis. Even if we would try to define the exposure to macro-economic fluctuations by the month of birth we cannot determine the exact month of the beginning or the end of the recession or the boom period. Therefore we decided to link the GDP information with three time periods $(\mathrm{t}, \mathrm{t}-1, \mathrm{t}+1)$ that are related to developmental stages, being aware that they are overlapping: the first period t-1 covers influences that occurred prior to conception and in-utero, the second period (t) combines developmental stages ranging from pre-conception to the first year of life, and the third $(t+1)$ covers parts of the first and second years of life. All three periods yield significant results in our study which is consistent with the different pathways that may link the economic environment early in life with later life health. The overlapping nature of the three periods may be one explanation why some effects for period t become insignificant once we control for conditions in periods $\mathrm{t}-1$ and $\mathrm{t}+1$.

Another limitation is that as yet no single causal mechanism from economic conditions early in life to health later in life has been identified. Given the possibility of various pathways, however, this can also be seen as an advantage of the economic indicator. It 
highlights the importance of health, family and social policies directed towards women who want to become mothers, as well as towards pregnant mothers and young children. In times of economic hardship these groups need special support to avoid negative longterm consequences on the cognitive abilities of the new generation. This would make the members of this new generation better prepared for financial decision-making at high ages, in a society where individual responsibility and opportunities for such decisions are larger than in the past. 
Table 1: Distribution of respondents with information about their cognitive status by country and wave of SHARE

\begin{tabular}{lrrrr}
\hline Country & Number & Percent & Wave I & $\begin{array}{l}\text { Wave II } \\
\text { (refreshment } \\
\text { sample) }\end{array}$ \\
\hline Austria & 738 & 4.04 & 717 & 21 \\
Belgium & 2,173 & 11.90 & 2,091 & 82 \\
Denmark & 1,544 & 8.45 & 921 & 623 \\
France & 1,834 & 10.04 & 1,504 & 330 \\
Germany & 1,218 & 6.67 & 971 & 247 \\
Greece & 1,781 & 9.75 & 1,405 & 376 \\
Italy & 2,265 & 12.40 & 1,626 & 639 \\
Netherlands & 1,840 & 10.08 & 1,544 & 296 \\
Spain & 1,937 & 10.61 & 1,528 & 409 \\
Sweden & 2,118 & 11.60 & 1,744 & 374 \\
Switzerland & 814 & 4.46 & 504 & 310 \\
\hline Total & 18,262 & 100.00 & 14,555 & 3,707 \\
\hline
\end{tabular}


Table 2: Boom and recession periods in the eleven SHARE countries

\begin{tabular}{lll}
\hline Country & Boom & Recession \\
\hline Austria & $1911-13,1925-30,1939$ & $1915-21,1932-35$ \\
Belgium & $1911-13,1923-24,1926-30,1937$, & $1917-21,1932,1941-46$ \\
& 1939 & \\
Denmark & $1911,1913-14,1923,1929-1931$, & $1917-22,1925,1940-43,1945$ \\
& $1935-1939$ & \\
France & $1912-13,1924-26,1928-30,1936-$ & $1910,1917-1921,1932,1941-45$ \\
& 39 & \\
Germany & $1910-13,1927-29,1937-39$ & $1915-17,1919-20,1923-24,1931-$ \\
Greece & $1921,1936-1940$ & 34 \\
Italy & $1909,1915-18,1929,1937-42$ & $1920,1931,1942-1946$ \\
& & $1902,1904,1920-1924,1931$, \\
Netherlands & $1912-13,1926-30,1936-40$ & $1908,1916-20,1934,1942-46$ \\
Spain & $1901,1927-35,1943-44$ & $1905,1910,1917-21,1936-1939$, \\
& $1899,1907,1913-16,1929-30$, & 1941 \\
Sweden & $1936-1939$ & $1905,1918-19,1921-22,1932-33$, \\
& $1899,1906,1910-1912,1925-30$, & $1903,1917-1922,1936,1941-$ \\
Switzerland & 1946 & 1944 \\
\hline
\end{tabular}


Table 3: Descriptive statistics

\begin{tabular}{|c|c|c|c|}
\hline Variable & Value & Number & Percent \\
\hline \multirow[t]{2}{*}{ Gender } & Male & 8,462 & 46.34 \\
\hline & Female & 9,800 & 53.66 \\
\hline \multirow[t]{7}{*}{ Age } & $60-64$ & 4,031 & 22.07 \\
\hline & $65-69$ & 4,486 & 24.56 \\
\hline & $70-74$ & 3,965 & 21.71 \\
\hline & $75-79$ & 3,002 & 16.44 \\
\hline & $80-84$ & 1,821 & 9.97 \\
\hline & $85-89$ & 679 & 3.72 \\
\hline & $90+$ & 278 & 1.52 \\
\hline \multirow[t]{3}{*}{ Education } & Low & 15,153 & 82.98 \\
\hline & High & 2,864 & 15.68 \\
\hline & Other/unknown & 245 & 1.34 \\
\hline \multirow[t]{3}{*}{ Business Cycle in year of birth $(t)$} & Recession $\mathrm{t}$ & 5,476 & 29.99 \\
\hline & Average $t$ & 6,551 & 35.87 \\
\hline & Boom t & 6,235 & 34.14 \\
\hline \multirow{3}{*}{$\begin{array}{l}\text { Business Cycle in year before birth } \\
(\mathrm{t}-1)\end{array}$} & Recession $\mathrm{t}-1$ & 5,292 & 28.98 \\
\hline & Average t-1 & 6,624 & 36.27 \\
\hline & Boom t-1 & 6,346 & 34.75 \\
\hline \multirow{3}{*}{$\begin{array}{l}\text { Business Cycle in year after birth } \\
(\mathrm{t}+1)\end{array}$} & Recession $\mathrm{t}+1$ & 5,833 & 31.94 \\
\hline & Average $\mathrm{t}+1$ & 6,371 & 34.89 \\
\hline & Boom t+1 & 6,058 & 33.17 \\
\hline \multirow[t]{2}{*}{ WWI (born during...) } & No & 18,035 & 98.76 \\
\hline & Yes & 227 & 1.24 \\
\hline \multirow[t]{2}{*}{ Family Status } & spouse/partner & 12,871 & 70.48 \\
\hline & Single & 5,391 & 29.52 \\
\hline \multirow[t]{6}{*}{ Number of children } & 0 & 1,671 & 9.15 \\
\hline & 1 & 2,266 & 12.41 \\
\hline & 2 & 4,497 & 24.62 \\
\hline & 3 & 2,493 & 13.65 \\
\hline & $4+$ & 1,947 & 10.66 \\
\hline & no information & 5,388 & 29.50 \\
\hline \multirow[t]{5}{*}{ Body-mass-index } & below 18.5 -underweight & 248 & 1.36 \\
\hline & $18.5-24.9-$ normal & 6,734 & 36.87 \\
\hline & 25-29.9 - overweight & 7,902 & 43.27 \\
\hline & 30 and above - obese & 3,004 & 16.45 \\
\hline & Missing & 374 & 2.05 \\
\hline \multirow[t]{2}{*}{ Activities of daily living } & no ADL limitations & 16,050 & 87.89 \\
\hline & $1+\mathrm{ADL}$ limitations & 2,212 & 12.11 \\
\hline \multirow[t]{2}{*}{ Depression Symptoms } & No & 13,617 & 74.56 \\
\hline & Yes & 4,645 & 25.44 \\
\hline \multirow[t]{4}{*}{ Smoking } & yes, currently & 2,572 & 14.08 \\
\hline & never smoked & 10,344 & 56.64 \\
\hline & Stopped & 5,320 & 29.13 \\
\hline & Missing & 26 & 0.14 \\
\hline \multirow[t]{2}{*}{ Proxy respondent } & No & 17,910 & 98.07 \\
\hline & Yes & 352 & 1.93 \\
\hline \multicolumn{4}{|l|}{ Doctor told you had: } \\
\hline Heart Attack & Yes & 2,925 & 16.02 \\
\hline Hypertension & Yes & 6,210 & 34.01 \\
\hline High blood cholesterol & Yes & 4,132 & 22.63 \\
\hline Stroke & Yes & 843 & 4.62 \\
\hline Diabetes & Yes & 2,173 & 11.90 \\
\hline Chronic lung disease & Yes & 1,179 & 6.46 \\
\hline Asthma & Yes & 890 & 4.87 \\
\hline Arthritis & Yes & 4,467 & 24.46 \\
\hline
\end{tabular}


Osteoporosis

Cancer

Stomach/duod./peptic ulcer

Parkinson

Cataracts

Hip/femoral fracture
1,729

1,212

1,144

150

2,089

492
9.47

6.26

0.82

11.44

2.69 
Table 4: Marginal effects of an average or boom birth year (year $\mathrm{t}$ ) for the total population, and by education (recession is the reference category).

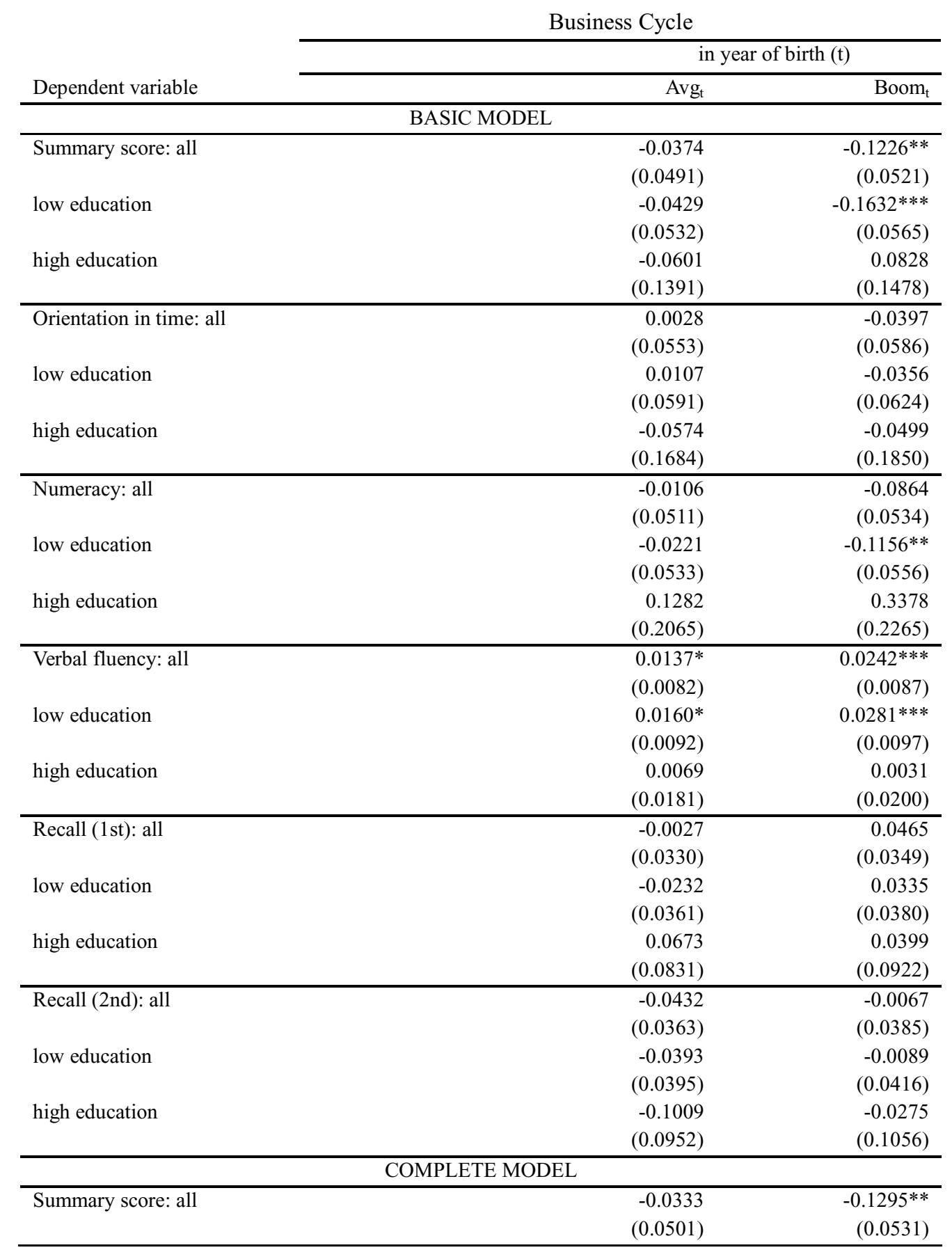

All cells contain marginal effects reported from logistic regression models (summary score, orientation in time, numeracy) or linear regression (verbal fluency, first and delayed recall). Standard errors are in parentheses. Basic models control for sex, age, 
WWI, country and education (all) or split by education. The complete model in addition controls for family status, number of children, BMI, ADL, depression, smoking, chronic disease, proxy answer. ${ }^{* * *} \mathrm{p}<=0.01 ; * * \mathrm{p}<=0.05 ;{ }^{*} \mathrm{p}<=0.1$ 
Table 5: Marginal effects of an average or boom birth year (year $t$ ), year prior to birth (year $\mathrm{t}-1$ ), and year after the birth year (year $\mathrm{t}+1$ ). Recession is the reference category.

Business Cycle

\begin{tabular}{|c|c|c|c|c|c|c|}
\hline \multirow[b]{2}{*}{$\begin{array}{l}\text { Dependent } \\
\text { variable }\end{array}$} & \multicolumn{2}{|c|}{ in year of birth $(\mathrm{t})$} & \multicolumn{2}{|c|}{ in year before birth (t-1) } & \multicolumn{2}{|c|}{ in year after birth $(\mathrm{t}+1)$} \\
\hline & $\operatorname{Avg}_{t}$ & Boom $_{t}$ & $\operatorname{Avg}_{t-1}$ & Boom $_{t-1}$ & $\operatorname{Avg}_{t+1}$ & Boom $_{t+1}$ \\
\hline Summary score: & & & & & & \\
\hline all & $\begin{array}{r}-0.0565 \\
(0.0562)\end{array}$ & $\begin{array}{c}-0.1485^{*} \\
(0.0797)\end{array}$ & $\begin{array}{r}0.0390 \\
(0.0507)\end{array}$ & $\begin{array}{r}-0.0142 \\
(0.0630)\end{array}$ & $\begin{array}{r}0.0666 \\
(0.0539)\end{array}$ & $\begin{array}{r}0.0836 \\
(0.0652)\end{array}$ \\
\hline low education & $\begin{array}{r}-0.0659 \\
(0.0608)\end{array}$ & $\begin{array}{r}-0.1985^{* *} \\
(0.0865)\end{array}$ & $\begin{array}{r}0.0467 \\
(0.0546)\end{array}$ & $\begin{array}{l}-0.0075 \\
(0.0682)\end{array}$ & $\begin{array}{r}0.0654 \\
(0.0586)\end{array}$ & $\begin{array}{r}0.0951 \\
(0.0709)\end{array}$ \\
\hline high education & $\begin{array}{l}-0.0721 \\
(0.1611)\end{array}$ & $\begin{array}{r}0.0240 \\
(0.2215)\end{array}$ & $\begin{array}{r}-0.1496 \\
(0.1481)\end{array}$ & $\begin{array}{r}-0.0317 \\
(0.1784)\end{array}$ & $\begin{array}{r}0.1410 \\
(0.1503)\end{array}$ & $\begin{array}{r}0.1086 \\
(0.1831)\end{array}$ \\
\hline $\begin{array}{l}\text { Orientation in } \\
\text { time: all }\end{array}$ & $\begin{array}{r}0.0220 \\
(0.0628)\end{array}$ & $\begin{array}{r}0.0384 \\
(0.0882)\end{array}$ & $\begin{array}{r}0.1215^{* *} \\
(0.0579)\end{array}$ & $\begin{array}{r}0.0180 \\
(0.0719)\end{array}$ & $\begin{array}{c}-0.1178^{*} \\
(0.0608)\end{array}$ & $\begin{array}{r}-0.1359^{*} \\
(0.0733)\end{array}$ \\
\hline low education & $\begin{array}{r}0.0145 \\
(0.0670)\end{array}$ & $\begin{array}{l}-0.0025 \\
(0.0944)\end{array}$ & $\begin{array}{r}0.1276 * * \\
(0.0619)\end{array}$ & $\begin{array}{r}0.0654 \\
(0.0770)\end{array}$ & $\begin{array}{c}-0.1114 * \\
(0.0653)\end{array}$ & $\begin{array}{r}-0.1145 \\
(0.0784)\end{array}$ \\
\hline high education & $\begin{array}{r}0.0535 \\
(0.1926)\end{array}$ & $\begin{array}{r}0.2183 \\
(0.2652)\end{array}$ & $\begin{array}{r}0.0181 \\
(0.1756)\end{array}$ & $\begin{array}{l}-0.2376 \\
(0.2145)\end{array}$ & $\begin{array}{l}-0.1130 \\
(0.1812)\end{array}$ & $\begin{array}{l}-0.1901 \\
(0.2242\end{array}$ \\
\hline Numeracy: all & $\begin{array}{l}-0.0029 \\
(0.0572)\end{array}$ & $\begin{array}{l}-0.0511 \\
(0.0813)\end{array}$ & $\begin{array}{l}-0.0220 \\
(0.0532)\end{array}$ & $\begin{array}{l}-0.1001 \\
(0.0659)\end{array}$ & $\begin{array}{r}0.0599 \\
(0.0560)\end{array}$ & $\begin{array}{r}0.0628 \\
(0.0676)\end{array}$ \\
\hline low education & $\begin{array}{r}-0.0133 \\
(0.0596)\end{array}$ & $\begin{array}{r}-0.0783 \\
(0.0847)\end{array}$ & $\begin{array}{r}-0.0234 \\
(0.0554)\end{array}$ & $\begin{array}{r}-0.0896 \\
(0.0687)\end{array}$ & $\begin{array}{r}0.0555 \\
(0.0587)\end{array}$ & $\begin{array}{r}0.0465 \\
(0.0705)\end{array}$ \\
\hline high education & $\begin{array}{r}0.1433 \\
(0.2420)\end{array}$ & $\begin{array}{r}0.2605 \\
(0.3380)\end{array}$ & $\begin{array}{r}-0.2168 \\
(0.2195)\end{array}$ & $\begin{array}{r}-0.1612 \\
(0.2633)\end{array}$ & $\begin{array}{r}0.0319 \\
(0.2252) \\
\end{array}$ & $\begin{array}{r}0.3197 \\
(0.2781)\end{array}$ \\
\hline Verbal Fluency: & & & & & & \\
\hline all & $\begin{array}{c}0.0155^{*} \\
(0.0093)\end{array}$ & $\begin{array}{l}0.0243 * \\
(0.0133)\end{array}$ & $\begin{array}{r}-0.0124 \\
(0.0085)\end{array}$ & $\begin{array}{r}0.0037 \\
(0.0106)\end{array}$ & $\begin{array}{l}-0.0007 \\
(0.0090)\end{array}$ & $\begin{array}{c}-0.0090 \\
(0.0110)\end{array}$ \\
\hline low education & $\begin{array}{r}0.0168 \\
(0.0104)\end{array}$ & $\begin{array}{l}0.0251^{*} \\
(0.0150)\end{array}$ & $\begin{array}{r}-0.0118 \\
(0.0095)\end{array}$ & $\begin{array}{r}0.0060 \\
(0.0119)\end{array}$ & $\begin{array}{l}-0.0010 \\
(0.0102)\end{array}$ & $\begin{array}{r}-0.0064 \\
(0.0123)\end{array}$ \\
\hline high education & $\begin{array}{r}0.0176 \\
(0.0209)\end{array}$ & $\begin{array}{r}0.0266 \\
(0.0293)\end{array}$ & $\begin{array}{r}-0.0096 \\
(0.0192)\end{array}$ & $\begin{array}{r}-0.0110 \\
(0.0231)\end{array}$ & $\begin{array}{l}-0.0116 \\
(0.0194)\end{array}$ & $\begin{array}{r}-0.0331 \\
(0.0242)\end{array}$ \\
\hline Recall $\left(1^{\text {st }}\right)$ : all & $\begin{array}{r}0.0156 \\
(0.0376)\end{array}$ & $\begin{array}{r}0.0821 \\
(0.0538)\end{array}$ & $\begin{array}{r}-0.0348 \\
(0.0343)\end{array}$ & $\begin{array}{r}-0.0188 \\
(0.0427)\end{array}$ & $\begin{array}{l}-0.0146 \\
(0.0362)\end{array}$ & $\begin{array}{r}-0.0490 \\
(0.0442)\end{array}$ \\
\hline low education & $\begin{array}{r}-0.0077 \\
(0.0410)\end{array}$ & $\begin{array}{r}0.0592 \\
(0.0589)\end{array}$ & $\begin{array}{r}-0.0556 \\
(0.0374)\end{array}$ & $\begin{array}{r}-0.0312 \\
(0.0469)\end{array}$ & $\begin{array}{r}0.0087 \\
(0.0399)\end{array}$ & $\begin{array}{r}-0.0206 \\
(0.0484)\end{array}$ \\
\hline high education & $\begin{array}{r}0.1360 \\
(0.0961) \\
\end{array}$ & $\begin{array}{l}0.2234^{*} \\
(0.1352) \\
\end{array}$ & $\begin{array}{r}0.0951 \\
(0.0883) \\
\end{array}$ & $\begin{array}{r}-0.0396 \\
(0.1065) \\
\end{array}$ & $\begin{array}{r}-0.1990 * * \\
(0.0892) \\
\end{array}$ & $\begin{array}{r}-0.2646^{* *} \\
(0.1113) \\
\end{array}$ \\
\hline Recall $\left(2^{\text {nd }}\right):$ all & $\begin{array}{r}-0.0261 \\
(0.0414)\end{array}$ & $\begin{array}{r}0.0383 \\
(0.0593)\end{array}$ & $\begin{array}{r}-0.0269 \\
(0.0378)\end{array}$ & $\begin{array}{r}-0.0290 \\
(0.0471)\end{array}$ & $\begin{array}{r}0.0177 \\
(0.0399)\end{array}$ & $\begin{array}{r}-0.0458 \\
(0.0487)\end{array}$ \\
\hline low education & $\begin{array}{r}-0.0317 \\
(0.0449)\end{array}$ & $\begin{array}{r}0.0102 \\
(0.0644)\end{array}$ & $\begin{array}{l}-0.0445 \\
(0.0410)\end{array}$ & $\begin{array}{r}-0.0257 \\
(0.0513)\end{array}$ & $\begin{array}{r}0.0490 \\
(0.0437)\end{array}$ & $\begin{array}{l}-0.0084 \\
(0.0530)\end{array}$ \\
\hline high education & $\begin{array}{r}-0.0160 \\
(0.1101)\end{array}$ & $\begin{array}{r}0.2005 \\
(0.1549)\end{array}$ & $\begin{array}{r}0.1099 \\
(0.1011)\end{array}$ & $\begin{array}{r}-0.0733 \\
(0.1220)\end{array}$ & $\begin{array}{r}-0.2046^{* *} \\
(0.1022)\end{array}$ & $\begin{array}{r}-0.2966 * * \\
(0.1276)\end{array}$ \\
\hline $\begin{array}{l}\text { Summary score: } \\
\text { all }\end{array}$ & $\begin{array}{r}-0.0534 \\
(0.0573)\end{array}$ & $\begin{array}{l}-0.1585 \\
(0.0813)\end{array}$ & $\begin{array}{r}0.0455 \\
(0.0517)\end{array}$ & $\begin{array}{r}-0.0048 \\
(0.0642)\end{array}$ & $\begin{array}{r}0.0564 \\
(0.0550)\end{array}$ & $\begin{array}{r}0.0784 \\
(0.0665)\end{array}$ \\
\hline
\end{tabular}


All cells contain marginal effects reported from logistic regression models (summary score, orientation in time, numeracy) or linear regression (verbal fluency, first and delayed recall). Standard errors are in parentheses. Basic models control for sex, age, WWI, country and education (all) or split by education. The complete model in addition controls for family status, number of children, BMI, ADL, depression, smoking, chronic disease, proxy answer. *** $\mathrm{p}<=0.01 ; * \mathrm{p}<=0.05 ; \mathrm{p}<=0.1$ 
Table 6: Marginal effects of the explanatory variables on the summary score of cognitive functioning

\begin{tabular}{|c|c|c|}
\hline Variables & $\mathrm{ME}$ & Standard error \\
\hline \multicolumn{3}{|l|}{ Gender (RG: males) } \\
\hline Females & -0.0177 & $(0.0419)$ \\
\hline \multicolumn{3}{|l|}{ Age (RG: 60-64) } \\
\hline $65-69$ & $0.5096^{* * *}$ & $(0.0586)$ \\
\hline $70-74$ & $0.9042 * * *$ & $(0.0578)$ \\
\hline $75-79$ & $1.3808 * * *$ & $(0.0684)$ \\
\hline $80-84$ & $1.7838 * * *$ & $(0.0787)$ \\
\hline $85-89$ & $2.3580 * * *$ & $(0.1277)$ \\
\hline $90+$ & $3.1173 * * *$ & $(0.2529)$ \\
\hline \multicolumn{3}{|l|}{ Education (RG: low) } \\
\hline High & $-1.2316^{* * *}$ & $(0.0536)$ \\
\hline refusal/don't know/still in school/other & -0.0104 & $(0.1531)$ \\
\hline \multicolumn{3}{|c|}{ Business Cycle in the year of birth (t) (RG: Recession $)$} \\
\hline Average $_{t}$ & -0.0333 & $(0.0501)$ \\
\hline Boom $_{t}$ & $-0.1295^{* *}$ & $(0.0531)$ \\
\hline WWI & 0.1912 & $(0.2464)$ \\
\hline \multicolumn{3}{|l|}{ Family Status (RG: Spouse/Partner) } \\
\hline Single & $0.2069^{* * *}$ & $(0.0476)$ \\
\hline \multicolumn{3}{|l|}{ Nr. of children (RG: 0 ) } \\
\hline 1 & -0.0066 & $(0.0779)$ \\
\hline 2 & -0.0794 & $(0.0704)$ \\
\hline 3 & -0.0256 & $(0.0776)$ \\
\hline $4+$ & $0.1742 * *$ & $(0.0826)$ \\
\hline No information & $-0.1228 *$ & $(0.0740)$ \\
\hline \multicolumn{3}{|l|}{ BMI (RG: below 18.5 -underweight) } \\
\hline $18.5-24.9-$ normal & $-0.3389 * *$ & $(0.1599)$ \\
\hline 25-29.9 - overweight & -0.2457 & $(0.1605)$ \\
\hline 30 and above - obese & -0.1755 & $(0.1645)$ \\
\hline refusal/dk/miss & $0.6375^{* * *}$ & $(0.2329)$ \\
\hline \multicolumn{3}{|l|}{ ADL (RG: no ADL limitations) } \\
\hline $1+\mathrm{ADL}$ limitations & $0.5186^{* * *}$ & $(0.0643)$ \\
\hline \multicolumn{3}{|l|}{ Depression Symptoms (RG: No) } \\
\hline Yes & $0.4976^{* * *}$ & $(0.0446)$ \\
\hline \multicolumn{3}{|l|}{ Smoking (RG: Yes, currently) } \\
\hline Never & -0.0221 & $(0.0542)$ \\
\hline Stopped & $-0.2300 * * *$ & $(0.0575)$ \\
\hline No information & -0.2586 & $(0.5454)$ \\
\hline \multicolumn{3}{|l|}{ Proxy (RG: No) } \\
\hline Yes & $1.1814 * * *$ & $(0.1990)$ \\
\hline \multicolumn{3}{|l|}{ Doctor told you had: } \\
\hline Heart Attack & $0.1663^{* * *}$ & $(0.0507)$ \\
\hline Hypertension & 0.0154 & $(0.0401)$ \\
\hline High blood cholesterol & -0.0168 & $(0.0449)$ \\
\hline Stroke & $0.4891 * * *$ & $(0.0901)$ \\
\hline Diabetes & $0.1990 * * *$ & $(0.0570)$ \\
\hline Chronic lung disease & $0.1526^{* *}$ & $(0.0761)$ \\
\hline Asthma & -0.0200 & $(0.0854)$ \\
\hline Arthritis & 0.0090 & $(0.0446)$ \\
\hline Osteoporosis & -0.0123 & $(0.0646)$ \\
\hline
\end{tabular}


Stomach/duodenal/

peptic ulcer

Parkinson

$0.7580 * * *$

(0.2323)

Cataracts

$-0.1023 *$

$(0.0599)$

Hip/femoral fracture

0.1124

(0.1174)

Marginal effects are from a logistic regression model. Standard errors are in parentheses. $* * * \mathrm{p}<=0.01 ; * * \mathrm{p}<=0.05 ; * \mathrm{p}<=0.1$; 
Figure 1: Distribution of single items orientation in time (A), first recall (B), verbal fluency $(C)$, numeracy $(D)$, delayed recall $(E)$, summary score $(F)$
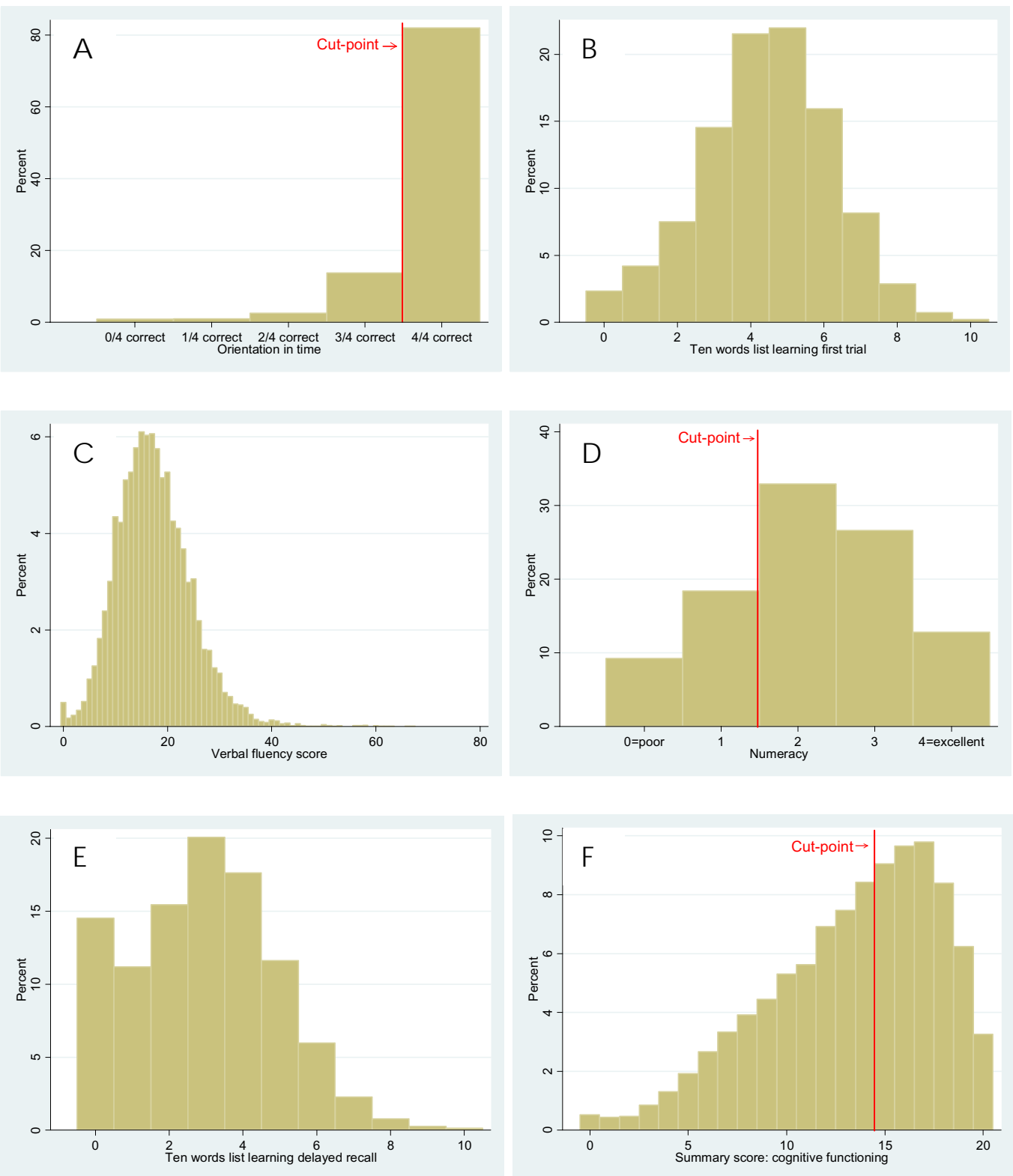
Figure 2: Cyclical components of log real GDP per capita for the eleven SHARE countries
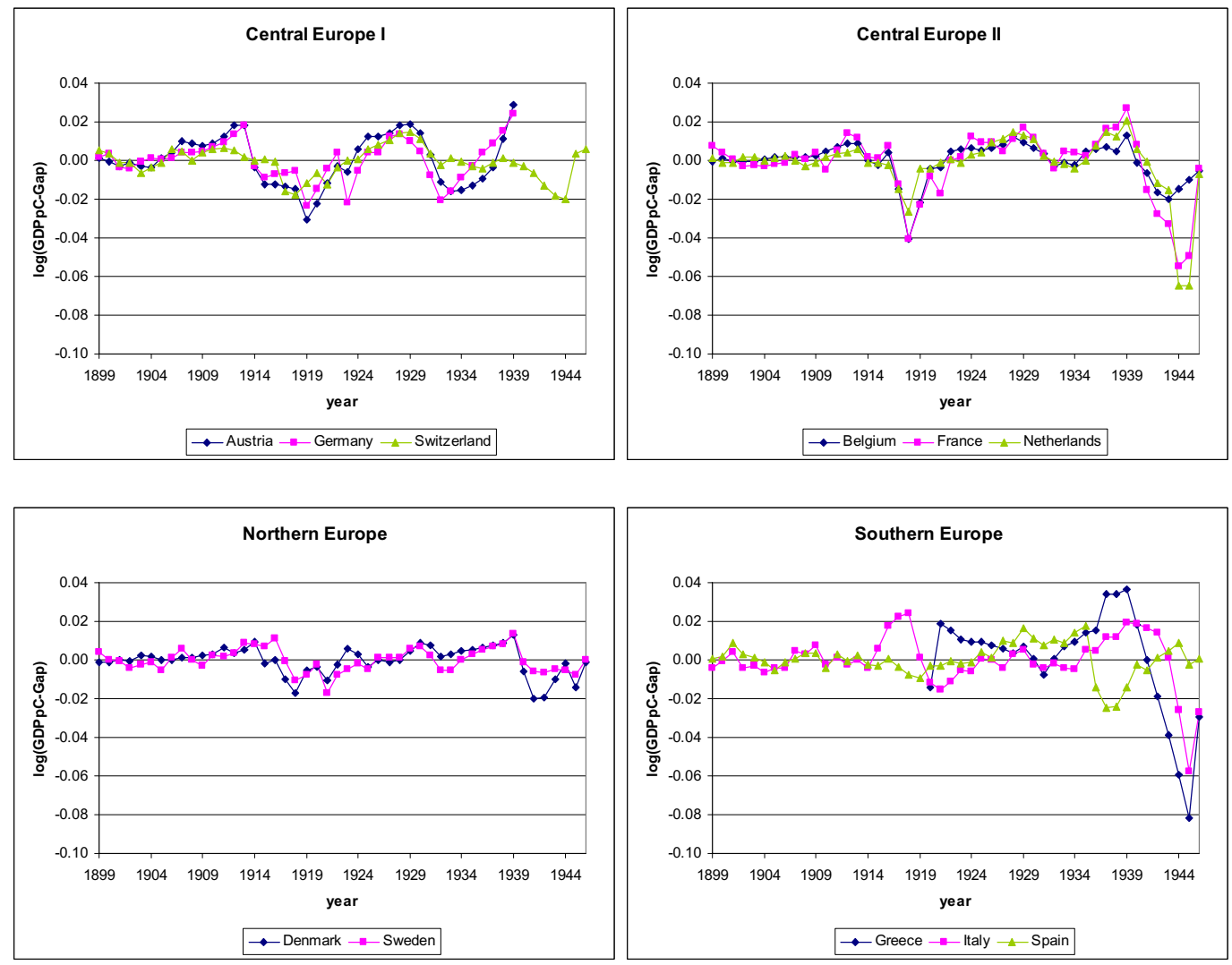


\section{References}

1. Christelis D, Jappelli T, Padula M (2010) Cognitive abilities and portfolio choice. Eur Econ Rev 54(1): 18-38.

2. Banks J, Oldfield Z (2007) Understanding pensions: cognitive function, numerical ability and retirement saving. Fiscal Studies 28: 143-170.

3. Smith JP, McArdle JJ, Willis R (2010) Financial Decision Making and Cognition in a Family Context. Econ J 120(549): 363-380.

4. Van den Berg GJ, Lindeboom M, Portrait F (2006) Economic conditions early in life and individual mortality. Am Econ Rev 96: 290-302.

5. Van den Berg GJ, Doblhammer G, Christensen K (2009) Exogenous determinants of early-life conditions, and mortality later in life. Soc Sci Med 68(9): 1591-1598, DOI: 10.1016/j.socscimed.2009.02.007.

6. Van den Berg GJ, Doblhammer G, Christensen K (2011) Being Born Under Adverse Economic Conditions Leads to a Higher Cardiovascular Mortality Rate Later in Life: Evidence Based on Individuals Born at Different Stages of the Business Cycle. Demography 48(2): 507-530.

7. Doblhammer G (2004) The late legacy of very early life. Demographic Research Monographs, Rostock: Max Planck Institute for Demographic Research.

8. Bengtsson T, Lindström M (2000) Childhood misery and disease in late life: The effects on mortality in old age of hazards experienced in early life, Southern Sweden, 1760-1894. Population Studies 54: 263-277.

9. Bengtsson T, Lindstrom M (2003) Airborne infectious diseases during infancy and mortality in later life in southern Sweden, 1766-1894. Int J Epidemiol 32: 286-294. 
10. Barker DJP (1994) Mothers, Babies, and Disease in Later Life. (British Medical Journal Publishing Group, London).

11. Forsdahl A (1977) Are poor living conditions in childhood and adolescence an important risk factor for arteriosclerotic heart disease? Br J Prev Soc Med 31:91-95.

12. Hales CN, Barker DJ (1992) Type 2 (non-insulin-dependent) diabetes mellitus: the thrifty phenotype hypothesis. Diabetologia 35(7): 595-601.

13. Bateson P (2001) Fetal experience and good adult design. Int J Epidemiol 30: 928-34.

14. Gluckman PD, Hanson MA (2004) Living with the past: evolution, development, and patterns of disease. Science 305:1733-1736.

15. Kuzawa C, Quinn EA (2009) Developmental Origins of Adult Function and Health: Evolutionary Hypotheses. Annu Rev Anthropol 38:131-147.

16. Morozink JA, Friedman EM, Coe CL, Ryff CD (2010) Socioeconomic and psychosocial predictors of interleukin-6 in the MIDUS national sample. Health Psychol 29(6): 626-635.

17. Miller GE, Chen E (2010) Harsh Family Climate in Early Life Presages the Emergence of a Proinflammatory Phenotype in Adolescence. Psychol Sci 21: 848856.

18. Cicchetti D, Toth SL (2005) Child maltreatment. Annu Rev Clin Psychol 1: 409-438.

19. Miller GE, et al. (2009) Low early-life social class leaves a biological residue manifest by decreased glucocorticoid and increased proinflammatory signaling. Proc Natl Acad Sci USA 106: 14716-14721.

20. Zhang TY, et al. (2006) Maternal programming of defensive responses through sustained effects on gene expression. Biol Psychol 73(1): 72-89. 
21. Cole SW, Hawkley LC, Arevalo JMG, Cacioppo JT (2010) Transcript origin analysis identifies antigen-presenting cells as primary targets of socially regulated gene expression in leukocytes. Proc Natl Acad Sci USA 108: 3080-3085.

22. Wells JC (2003) The thrifty phenotype hypothesis: thrifty offspring or thrifty mother? J Theor Biol 221: 143-161.

23. Chen E, Miller GE, Kobor MS, Cole SW (2010) Maternal warmth buffers the effects of low early-life socioeconomic status on pro-inflammatory signaling in adulthood. Mol Psychiatry: 1-9.

24. Finch CE, Crimmins EM (2004) Inflammatory Exposures and Historical Changes in Human Life Spans. Science 305(5691): 1736-1739.

25. Crimmins EM, Finch CE (2006) Infection, Inflammation, Height and Longevity. Proc Natl Acad Sci USA 103(2): 498-503.

26. McDade TW, Rutherford J, Adair L, Kuzawa CW (2010) Early origins of inflammation: microbial exposures in infancy predict lower levels of C-reactive protein in adulthood. Proc $R$ Soc B 277(1684): 1129-1137.

27. Costa DL (2000) Understanding the Twentieth Century Decline in Chronic Conditions among Older Men. Demography 37(1): 53-72.

28. Holliday M (1986) Body composition and energy needs during growth. Human Growth: A Comprehensive Treatise, eds Falkner F, Tanner JM (Plenum Press, New York), 2nd Ed, pp 117-139.

29. Kuzawa CW (1998) Adipose tissue in human infancy and childhood: an evolutionary perspective. Am J Phys Anthropol 27:177-209. 
30. Drury SS, et al. (2011) Telomere length and early severe social deprivation: linking early adversity and cellular aging. Mol Psychiatry: 1-9.

31. Holding PA, Snow RW (2001) Impact of Plasmodium Falciparum Malaria on Performance and Learning: Review of the Evidence. Am J Trop Med Hyg 64(1-2 Suppl): 68-75.

32. Costa DL (2005) Causes of Improving Health and Longevity at Older Ages: A Review of the Explanations. Genus LXI(1): 21-38.

33. Landrigan PJ, et al. (2005) Early environmental origins of neurodegenerative disease in later life. Environ Health Perspect 113(9): 1230-1233.

34. Miller DB, O'Callaghan JP (2008) Do early-life insults contribute to the late-life development of Parkinson and Alzheimer diseases? Metabolism 57(2): 44-49.

35. Martin-Ruiz C, et al. (2006) Telomere length predicts poststroke mortality, dementia,and cognitive decline. Ann Neurol 60: 174-180.

36. Tyrka A, et al. (2009) Childhood maltreatment and telomere shortening: preliminary support for an effect on early stress on cellular aging. Biol Psychiatry 67: 531-534.

37. Kananen L, et al. (2010) Childhood adversities are associated with shorter telomere length at adult age both in individuals with an anxiety disorder and controls. PLoS ONE 5(5): e10826.

38. O'Donovan A, et al. (2011) Childhood Trauma Associated with Short Leukocyte Telomere Length in Posttraumatic Stress Disorder. Biol Psychiatry: DOI: 10.1016/j.biopsych.2011.01.035. 
39. Rufer N, et al. (1999) Telomere fluorescence measurements in granulocytes and $\mathrm{T}$ lymphocyte subsets point to a high turnover of hematopoietic stem cells and memory T cells in early childhood. J Exp Med 190: 157-167.

40. Cameron N, Demerath E (2002) Critical periods in human growth and their relationship to diseases of aging. Am J Phys Anthropol 35: 159-184.

41. De Groot RHM et al. (2011) Prenatal famine exposure and cognition at age 59 years. Int J Epidemiol 40: 327-337.

42. De Rooij SR, Wouters H, Yonker JE, Painter RC, Roseboom TJ (2010) Prenatal undernutrition and cognitive function in late adulthood. Proc Natl Acad Sci USA 107: 16881-16886.

43. Susser ES, Lin SP (1992) Schizophrenia after prenatal exposure to the Dutch Hunger Winter of 1944-45. Arch Gen Psychiatry 49: 983-988.

44. Saint-Clair D, Xu M, Wang P et al. (2005) Rates of adult schizophrenia following prenatal exposure to the Chinese Famine of 1959-61. JAMA 294: 557-562.

45. Brown AS, Susser ES (2008) Prenatal Deficiency and Risk of Adult Schizophrenia. Schizophrenia Bulletin 34(6): 1054-1063.

46. Lumey LH, Stein AD, Susser E (2011) Prenatal Famine and Adult Health. Annu Rev Public Health 32: 24.1-24.26.

47. Almond D, Mazumder B (2008) Health Capital and the Prenatal Environment: The Effect of Maternal Fasting During Pregnancy. NBER Working Paper No. 14428 (Natl Bur Econ Res, Cambridge MA). 
48. Almond D (2006) Is the 1918 Influenza Pandemic Over? Long-term Effects of in Utero Influenza Exposure in the Post-1940 US Population. J Polit Econ 114(4): 672712.

49. Case A, Paxson C (2009) Early Life Health and Cognitive Function in Old Age. Am Econ Rev 99(2): 104-109.

50. Van den Berg GJ, Deeg DJH, Lindeboom M, Portrait F (2010) The Role of EarlyLife Conditions in the Cognitive Decline due to Adverse Events Later in Life. Econ J 120(548): 411-428.

51. Brunson KL, et al. (2005) Mechanisms of late-onset cognitive decline after early-life stress. J Neurosci 25: 9328-9338.

52. Evans GW, Schamberg MA (2009) Childhood poverty, chronic stress, and adult working memory. Proc Natl Acad Sci USA 106(16): 6545-6549.

53. Snowdon DA, et al. (1996) Linguistic Ability in Early Life and Cognitive Function and Alzheimer's Disease in Late Life. Findings From the Nun Study. JAMA 275: 528532.

54. Snowdon DA, Greiner LH, Markesbery WR (2006) Linguistic Ability in Early Life and the Neuropathology of Alzheimer's Disease and Cerebrovascular Disease: Findings from the Nun Study. Ann N Y Acad Sci 903: 34-38.

55. Dahl G, Lochner L (2011) The impact of family income on child achievement: evidence from changes in the Earned Income Tax Credit. Am Econ Rev: forthcoming.

56. Duncan GJ (2006) Income and Child Well-Being. Geary Lecture Series 34, Dublin: ESRI. 
57. Borghans L, Duckworth A, Heckman JJ, Ter Weel B (2008) The economics and psychology of personality traits. J Human Res 43(4): 815-858.

58. Ziegler U (2011) Dementia in Germany: past trends and future developments. Dissertation (University of Rostock, Rostock).

59. Hodrick R, Prescott EC (1997) Postwar U.S. business cycles: an empirical investigation. J Money Credit Bank 29: 1-16.

60. Maddison A (2008) Statistics on World Population, GDP and Per Capita GDP, 12008 AD. (University of Groningen). Available at www.ggdc.net/maddison/Historical_Statistics/horizontal-file_02-2010.xls.

61. Wang PN, et al. (1997) Risk factors for Alzheimer's diesease: A case control study. Neuroepidemiology 16(5): 234-240.

62. Håkansson K, et al. (2009) Association between mid-life marital status and cognitive function in later life: population based cohort study. Br Med J 339(b2462): 1-8.

63. Buber I, Engelhardt H (2006) Children and mental health of elderly. European demographic research papers 3/2006 (Vienna Institute of Demography of the Austrian Academy of Sciences, Vienna).

64. Mond J, Rodgers B, Hay P, Owen C (2011) Mental Health Impairment in Underweight Women: Do Body Dissatisfaction and Eating-Disordered Behaviour Play a Role? BMC Public Health 11(1): 547.

65. Molarius A, et al. (2009) Mental health symptoms in relation to socio-economic conditions and lifestyle factors - a population-based study in Sweden. BMC Public Health 9: 302. 
66. Anstey KJ, von Sanden C, Salim A, O’Kearney R (2007) Smoking as a risk factor for dementia and cognitive decline: a meta-analysis of prospective studies. Am J Epidemiol 166(4): 367-378.

67. Landi F, et al. (2001) Functional status and clinical correlates in cognitively impaired community-living older people. J Geriatr Psychiatry Neurol 14(1): 21-27.

68. Greiner PA, Snowdon DA, Schmitt FA (1996) The loss of independence in activities of daily living: the role of low normal cognitive function in elderly nuns. Am J Public Health 86(1): 62-66.

69. Griffiths RA, et al. (1987) Depression, dementia and disability in the elderly. $B r J$ Psychiatry 150: 482-493.

70. Devanand DP, et al. (1996) Depressed mood and the incidence of Alzheimer's disease in the elderly living in the community. Arch Gen Psychiatry 53(2): 175-182.

71. Schulz LC (2010) The Dutch Hunger Winter and the developmental origins of health and disease. Proc Natl Acad Sci USA 107: 16757-16758. 


\section{Survey of Health, Aging and Retirement in Europe (SHARE)}

(www.share-project.org)

"This paper uses data from SHARELIFE release 1, as of November 24th 2010, or SHARE release 2.4.0, as of March 17th 2011. The SHARE data collection has been primarily funded by the European Commission through the 5th framework programme (project QLK6-CT-2001- 00360 in the thematic programme Quality of Life), through the 6th framework programme (projects SHARE-I3, RII-CT- 2006-062193, COMPARE, CIT5-CT-2005-028857, and SHARELIFE, CIT4-CT-2006-028812) and through the 7th framework programme (SHARE-PREP, 211909 and SHARE-LEAP, 227822). Additional funding from the U.S. National Institute on Aging (U01 AG09740-13S2, P01 AG005842, P01 AG08291, P30 AG12815, Y1-AG-4553-01 and OGHA 04-064, IAG BSR06-11, R21 AG025169) as well as from various national sources is gratefully acknowledged (see www.share-project.org for a full list of funding institutions)." 